\title{
Anatomy of the shrimp plant, Justicia brandegeana (Acanthaceae)
}

\author{
Caitlin S. O'Neill
}

\begin{abstract}
This manuscript was prepared under the supervision of Professor John Greenwood, Department of Molecular and Cellular Biology, College of Biological Science.
\end{abstract}

\begin{abstract}
Justicia brandegeana, commonly known as the shrimp plant, is a popular ornamental plant in North America. In the wild, it grows as a shrub in semi-arid climates. Little is documented on the anatomy of this plant, therefore the purpose of this study was to determine the anatomy of the shrimp plant at the cellular level through various hand sectioning and staining techniques. It was determined that many anatomical features of this plant were similar to those of a typical dicotyledonous plant. However, there were unique features of this plant that are related to its hot/dry environment. These include a layer of suberized parenchyma in the stem surrounding the vascular tissue, a thick band of secondary xylem in the stem and root, phi thickenings in cortical cells just inside the exodermis in mature root, and expansion of the Casparian bands in the endodermis consistent with the secondary growth of the vascular tissue in the root. Further research is necessary on similar species in this genus and family that have adapted to semi-arid environments in order to compare and contrast the adaptations found in the anatomy of J. brandegeana.
\end{abstract}

$J$ usticia brandegeana is a tropical shrub commonly known as the shrimp plant. ${ }^{1}$ This plant is classified as a eudicot angiosperm (flowering plant) belonging to the family Acanthaceae. ${ }^{2,3}$ The name "shrimp plant" can be attributed to the colourful bracts that surround the small flower of this plant that appear similar to a shrimp. ${ }^{4} \mathrm{~J}$. brandegeana is native to Mexico and has naturalized as a weed in Florida, USA. ${ }^{1,5}$ It is commonly grown as an outdoor ornamental plant in tropical and sub-tropical gardens, as well as an indoor ornamental plant in colder regions of the Americas. ${ }^{1,6}$ This species grows well in sandy/loamy soils and in warmer climates where temperatures do not go below $0^{\circ} \mathrm{C}$ in the winter. ${ }^{1}$ This plant will die off with winter frost.

When left to mature in a garden or in the wild, $J$. brandegeana will grow in clumps roughly $1-1.5 \mathrm{~m}$ tall and $1 \mathrm{~m}$ wide. ${ }^{1}$ At the tip of the long skinny stems, there is an arrangement of bracts that curves downward and surrounds the simple flowers. ${ }^{1}$ The bracts are often pink, however different cultivars of this species have bracts that are red, yellow, or lime green. ${ }^{1} \mathrm{~J}$. brandegeana continuously blooms as long as the temperature remains warm. The flower petals are fused together to form a tubular shape. ${ }^{6}$ The leaves are elliptic (rounded) and roughly $5-8 \mathrm{~cm}$ in length when mature. ${ }^{1}$ This plant is not to be confused with the golden shrimp plant (Pachystachys lutea) which has longer lanceolate leaves and bright yellow bracts that are more erect than those of $J$. brandegeana. $^{7}$

The family Acanthaceae is known for its epidermal cells that develop cystolith calcium carbonate crystals as a defense mechanism. ${ }^{8}$ To date, detailed information on the anatomy of the genus Justicia and the species J. brandegeana within the Acanthaceae family is lacking. Therefore the objective of this study is to determine the anatomy of the shrimp plant, $J$. brandegeana through the use of several laboratory techniques.

\section{MATERIALS AND MethodS}

The cultivar of $J$. brandegeana used in this study had lime green bracts with simple white flowers. There were four plants potted in the same pot that were all sampled for this study.

\section{Stem and Root}

Transverse, longitudinal, and tangential sections of the stem and root were made according to the methods outlined in Peterson et al., 2008. ${ }^{9}$ Sections were taken from younger tissue and older tissue to look for primary and secondary growth. The shoot apical meristem (SAM) and root apical meristem (RAM) were also sectioned. All staining and microscopy techniques were obtained from Peterson et al., 2008 and Peterson et al., 2009. ${ }^{9,10}$

Sections were stained with Toluidine Blue (TBO) to study cell/tissue organization and look for the presence of lignin or pectin in cell walls. Sections were also stained with Phloroglucinol to look for cell/tissue organization and the presence of lignin in secondary cell walls. Iodine Potassium Iodide $\left(\mathrm{I}_{2} \mathrm{KI}\right)$ was used to stain sections to look for starch grains in cells. Sudan III/IV and an ethanol solution were used to stain the lipids in cells. Sections were also stained with acid Fuchsin to look for protein deposits. All sections mentioned above were viewed under a compound microscope. Sections were also stained with Aniline Blue and viewed with an epifluorescence microscope (using UV 
light) in order to look for the presence of callose. Berberine hemi-sulfate $/ \mathrm{FeCl}_{3}$ was used to stain sections that were also viewed with an epifluorescence microscope to look for suberin, lignin, and callose. The dissecting microscope was used to observe the SAM and RAM and the trichomes.

\section{Leaves}

Nail polish impressions were made for adaxial (upper) and abaxial (lower) leaf surfaces as well as bracts according to methods outlined in Peterson et al., 2008. ${ }^{9}$ Structures on the epidermis including trichomes, stomatal complexes, crystals, and cell/tissue organization were observed. Transverse and tangential longitudinal sections were stained with TBO and viewed under the compound microscope. Tissue organization, cell organization and vascular bundles were observed. Sections of fresh leaf were also viewed under a compound microscope with crossed polarizers to examine the crystalline materials.

\section{Flowers}

Flowers were viewed under the dissecting microscope to differentiate the separate whorls. Individual flower parts were examined to determine whether the plant was perfect/imperfect and complete/incomplete. Flowers were also examined for the presence of trichomes and nectar.

\section{Other Techniques}

Apart from the standard ways of sectioning plant tissue (transverse, longitudinal and tangential sections), several other techniques were used to get smaller sections or to separate individual cells. Tissue was cleared and macerated based on the techniques described in Peterson et al., 2008. ${ }^{9}$ Plant tissue was cleared by placing in a $\mathrm{KOH}$ solution and heating. Tissue was also cleared using a boiling ethanol solution. Furthermore, tissue was macerated by placing in an $\mathrm{H}_{2} \mathrm{O}_{2}$ and acetic acid solution and heating. The solutions were then mounted on a slide, stained with TBO, and viewed under a compound microscope. Some macerated tissue was also observed with a cross polarizer. Individual cells, structures, and tissues were observed.

Finally, plant tissue that was difficult to hand section such as axillary buds, flowers, and meristems - was embedded in paraffin wax and a microtome was used to create very thin sections of plant tissue. Sections were mounted on a slide and viewed under a compound microscope.

\section{RESULTS}

\section{Stem}

Without a microscope, it was determined that the stem was quite rigid despite its thin appearance (Figure 1). The stem was bright green, and evenly covered with trichomes. There were four distinct ridges that extended longitudinally along the stem. There were also relatively large gaps along the stem between nodes and leaf pairs. Finally, the stem was

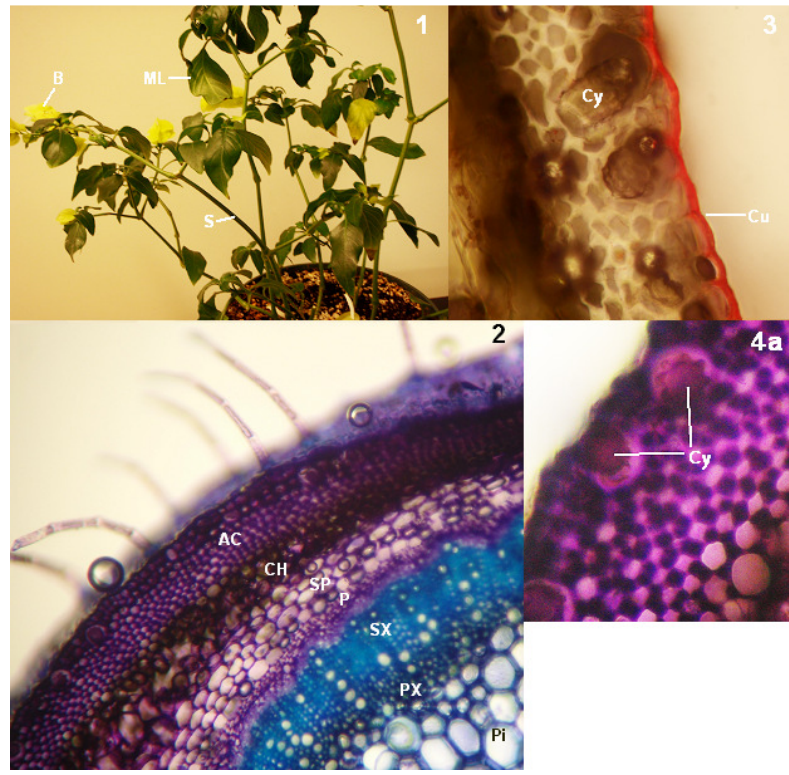

Figure 1: Shrimp plant showing mature leaf (ML), bracts (B), and stem (S).

Figure 2: Transverse section of stem stained with TBO showing the epidermis (E), angular collenchym (AC), chlorenchyma $(\mathrm{CH})$, suberized parenchyma (SP), phloem (P), secondary xylem (SX), primary xylem (PX), and parenchyma in the pith $(\mathrm{Pi})$.

Figure 3: Transverse section of stem stained with Sudan III/IV. The cuticle (Cu) stained pink. Cystolith crystal (Cy) is also visible.

Figure 4a: Cross section of stem stained with TBO shpwing cystolith crystals $(\mathrm{Cy})$. b. Longitudinal section of stem unstained with epifluorescence microscope with cystoliths just under epidermis.

quite tough and resistant to forces, which made it difficult to section with a razor.

The stem had several distinct tissue layers. In a transverse section, from the outside to the inside, the cell/tissue layers were as followed: epidermis, angular collenchyma, chlorenchyma, suberized parenchyma, phloem, secondary xylem, primary xylem, and parenchyma in the pith (Figure 2). These tissue layers are discussed in further detail in the following sections.

\section{Epidermis}

$J$. Brandegeana had a particularly thick cuticle covering the epidermis (Figure 3). The stem also had many multi-cellular trichomes projecting from the epidermal layer, as well as stomata. In regions where the trichomes extended from the epidermis, the cuticle was discontinuous (i.e. did not surround the trichomes). The stem generally had two epidermal cell layers except for the youngest stem tissue that was sampled. Additionally, just under the first epidermal layer, there were oval-shaped calcium carbonate crystals (cystoliths) (Figure 4a,b). These crystals were intermittent and lay roughly parallel to the surface of the stem. 


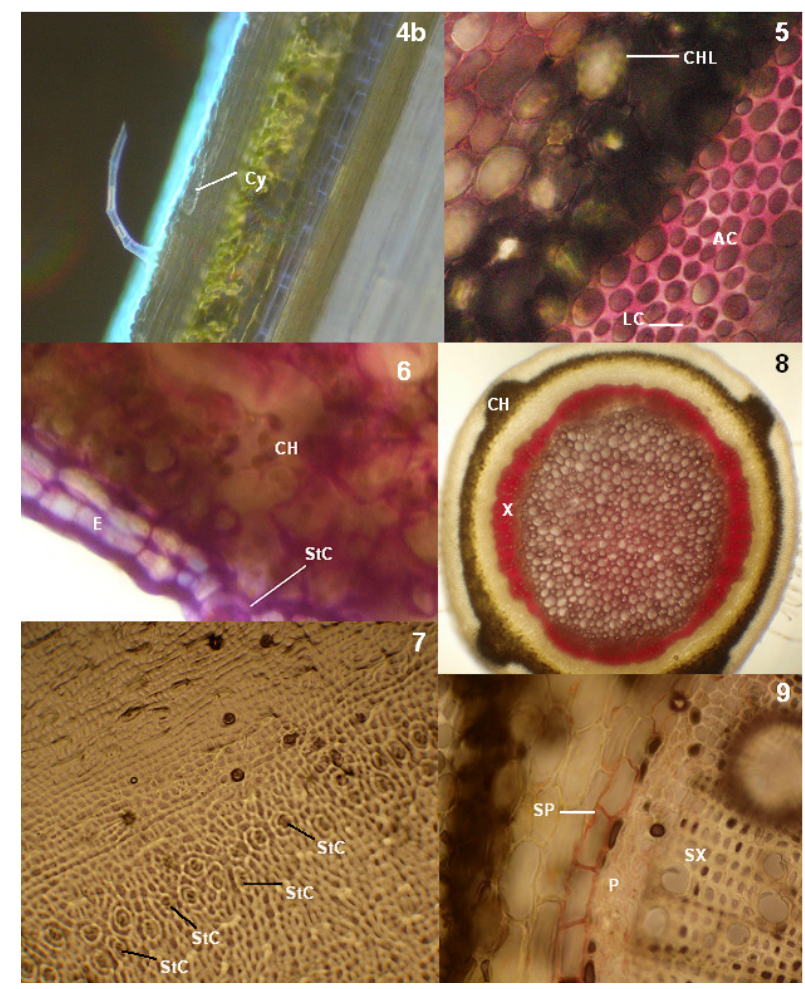

Figure 5: Cross section of stem stained with Acid Fuschin showing angular collenchyma (AC), lacunar collenchyma (LC), and chloroplasts (CHL) in the chlorenchyma.

Figure 6: Cross section of stem stained with TBO. Stomatal complex (StC) on epidermis (E) where chlorenchyma $(\mathrm{CH})$ reach the surface.

Figure 7: Nail polish impression showing strip of stomata (StC) along stem.

Figure 8: Cross section of stem stained with phloroglucinol showing extension of chlorenchyma (CH) towards epidermis. Xylem ring also visible $(X)$.

Figure 9: Cross section of stem stained with Sudan III/IV showing suberized parenchyma (SP) around phloem (P) and secondary xylem (SX).

Collenchyma and Chlorenchyma

Young and old sections of $J$. brandegeana stem had a thick layer of angular collenchyma just under the epidermis (Figure 5). A few lacunar collenchyma were also found within this tissue layer. Beneath this tissue layer, there was a layer of photosynthetic chlorenchyma. The band of collenchyma was interrupted by four patches of chlorenchyma that extended to the epidermis. This uneven thickening of collenchyma tissue forms the four ridges that are apparent along the stem. The areas where the chlorenchyma extend to the epidermis are thought to coincide with the strips of stomata that extend longitudinally along the stem (Figure 6-8).

\section{Suberized Parenchyma}

Between the vascular tissue and the chlorenchyma, there was a layer of parenchyma cells whose purpose and composition was difficult to determine. It was ruled out that they were immature fibers since they did not appear elongated in longitudinal sections, and they did not have lignified secondary cell walls. After attempting many different stains and techniques, it was determined that these cells (when mature) contain lipid content (likely suberin) in their cell walls since they stained pink with Sudan III/IV (Figure 9). Although unusual, this cell layer could be an endodermis in the stem.

\section{Vascular Tissue}

Just below the suberized parenchyma was a ring of phloem tissue. The xylem tissue was located further towards the pith. Although the original vascular bundles were not present, the arrangement of xylem and phloem was collateral. In longitudinal sections, individual sieve tube elements in the phloem were observed. There were sieve tube members that joined together with sieve plates to form long sieve tubes (Figure 10). Groupings of P-protein were also visible near the sieve plates in sieve tube members (Figure 10).

In all sections of the $J$. brandegeana stem - including the youngest tissue that was sampled - there was a thick band of secondary xylem tissue (Figure 11). Primary xylem was found towards the inside of this secondary xylem ring. In longitudinal sections, helical and annular secondary cell wall thickenings in the protoxylem were present (Figure 12a,b). Reticulate pitting in the secondary xylem was also evident (Figure 13). In the secondary xylem there were tracheids and vessel members. The vessel members were larger, and were joined together by perforation plates to form long vessels. The meristem that gave rise to this secondary growth was the vascular cambium that was located between the xylem and phloem tissue.

\section{Root}

Without a microscope, it was determined that the roots were fibrous - no distinction of a larger primary root but rather many long, thin, lateral roots. The roots had many root hairs that knotted together. In a transverse section, several distinct tissue layers were evident. In a young root (close to the root tip), from the outside to the inside, the cell/tissue layers were as follows: root hairs, epidermis, exodermis, angular collenchyma, parenchyma in cortex, endodermis with Casparian bands, pericycle, phloem, xylem, and parenchyma in the pith (Figure 14,15a,b).

Many roots were sectioned - young and old - and there was only one section without secondary growth in the vascular tissue. This section was taken very close to the root tip of a young root. All other root sections showed secondary growth of the vascular tissue (Figure 16). In the young root, the vascular arrangement was polyarch, with eight distinct strands of primary xylem and alternating primary phloem (Figure 14). In the more mature roots, this polyarch arrangement was still evident although the xylem tissue had expanded to form a ring towards the outside of the original bundles (Figure 16). Even the oldest root that was sampled 


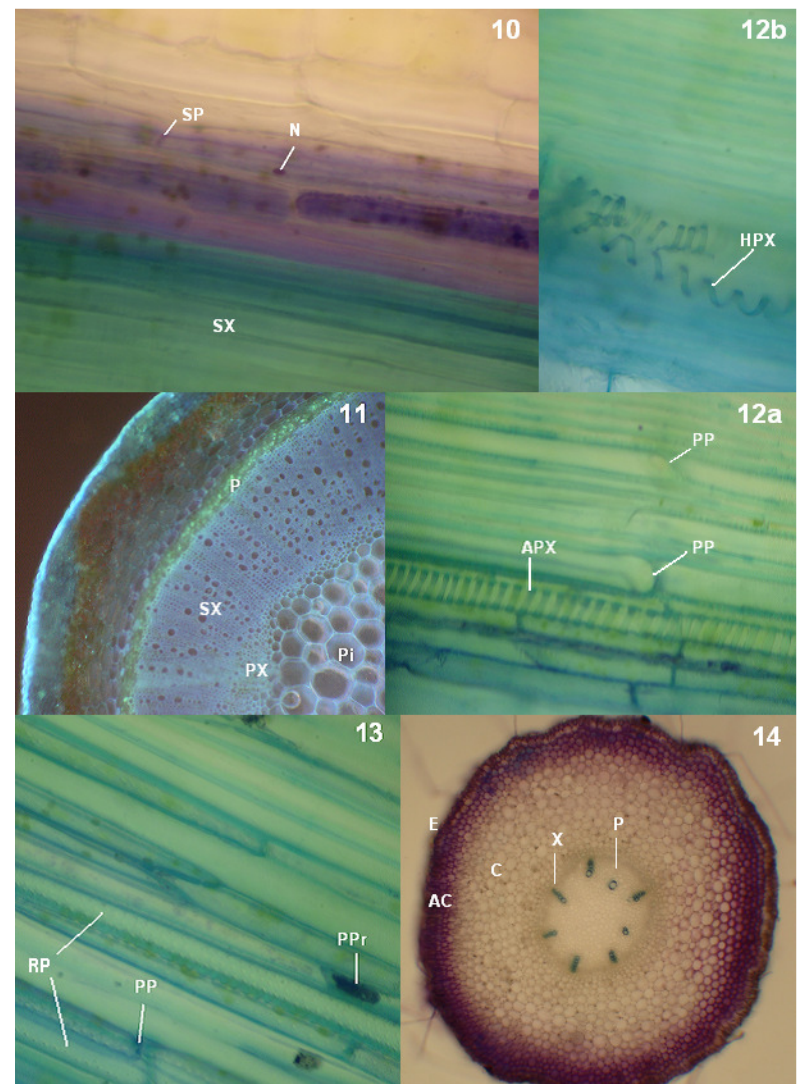

Figure 10: Longitudinal section of stem stained with TBO showing sieve plates (SP), the nucleus $(N)$ of a sieve tube element, and secondary xylem (SX) just below phloem.

Figure 11: Cross section of stem stained with Analine Blue showing the pith $(\mathrm{Pi})$, primary xylem $(\mathrm{PX})$, secondary xylem (SX), and phloem (P).

Figure 12a: Longitudinal section of stem stained with TBO showing perforation plates between tracheary elements (PP), and annular secondary cell wall thickenings in the protoxylem (APX). b. Helical thickenings are also present in the protoxylem (HPX).

Figure 13: Longitudinal section of stem stained with TBO showing reticulate pitting in secondary xylem (RP), perforation plates (PP) between tracheary elements, and P-protein (PPr) near the perforation plates.

Figure 14: Youngest root cross section stained with TBO showing epidermis (E), angular collenchyma (AC), cortex (C), phloem (P), and phloem. The polyarch arrangement with 8 vascular bundles is visible.

still had a pith in the middle of the root, which is uncommon for eudicots.

Furthermore, there was no evidence of periderm growth in the mature roots. An interesting thing about the secondary growth in the root was that the Casparian bands in the endodermis layer seemed to stretch and keep pace with the expansion of the vascular cylinder through anticlinal divisions (Figure 17). It is unclear whether this cell layer is actually still the endodermis with Casparian bands, or whether it is a newly formed layer of lignified or suberized parenchyma. Based on the fact that this cell layer was evident in all of the root sections (young and old), and that it seems to conform around the vascular tissue, it suggests that this layer may in fact be the endodermis. However, further research is needed on other plants to support this observation.

In the mature root, there seemed to be phi thickenings in layers of cortical cells that were first mistaken for Casparian bands in the exodermis (Figure 18). Since it is known that Casparian bands in the exodermis are often not present in older roots, these markings were examined more closely. They fluoresced when unstained under UV light, denoting that there is potentially lignin in the secondary cell wall thickenings. Also, the structure of the thickenings are very similar to the phi thickenings described on page 72 of Peterson et al. (2008). ${ }^{9}$ Other evidence that led to this conclusion is the fact that there are cells on the outside of these thickened cells that appear to be detaching from the root. These cells are likely the epidermal cells and some cortical cells that are sloughing off, leaving the lignified layer as the outermost layer for protection.

\section{Root Tip}

The organization of the root tip appears to be open since different cell layers cannot be traced back to one meristematic cell layer. The protoderm, ground meristem, vascular cambium, and root cap can all be distinguished (Figure 19). Several root hairs are also visible as well as starch grains for gravitropism.

\section{Leaves}

Without a microscope it was determined that the leaf organization of $J$. brandegeana is opposite and decussate, meaning that leaf pairs emerge from the stem at 90 degrees from each other. The leaves were also elliptic (oval-shaped with a small point) and roughly $5-8 \mathrm{~cm}$ in length. The leaf margin was entire, meaning that it was even and smooth throughout. The venation pattern was reticulate, with one midvein and a network of smaller veins.

Towards the tip of the stem, there were lime green bracts (modified leaves) that surrounded the white tubular flowers (Figure 20). These bracts had the same structure as the leaves, except for their smaller size $(2-3 \mathrm{~cm})$ and the fact that they were curled around the flowers in groups of three. There was roughly six to eight groupings of three bracts around one flower in one large patch. These groupings of bracts and flowers were what formed the shrimp-like shapes on the plant.

In a longitudinal section of the shoot apical meristem (SAM) - despite numerous trichomes - several tissue layers can be distinguished (Figure 21). There is a domed apical meristem, leaf primordia, and developing axillary buds. The opposite, decussate leaf organization can be seen again in this dissection. 


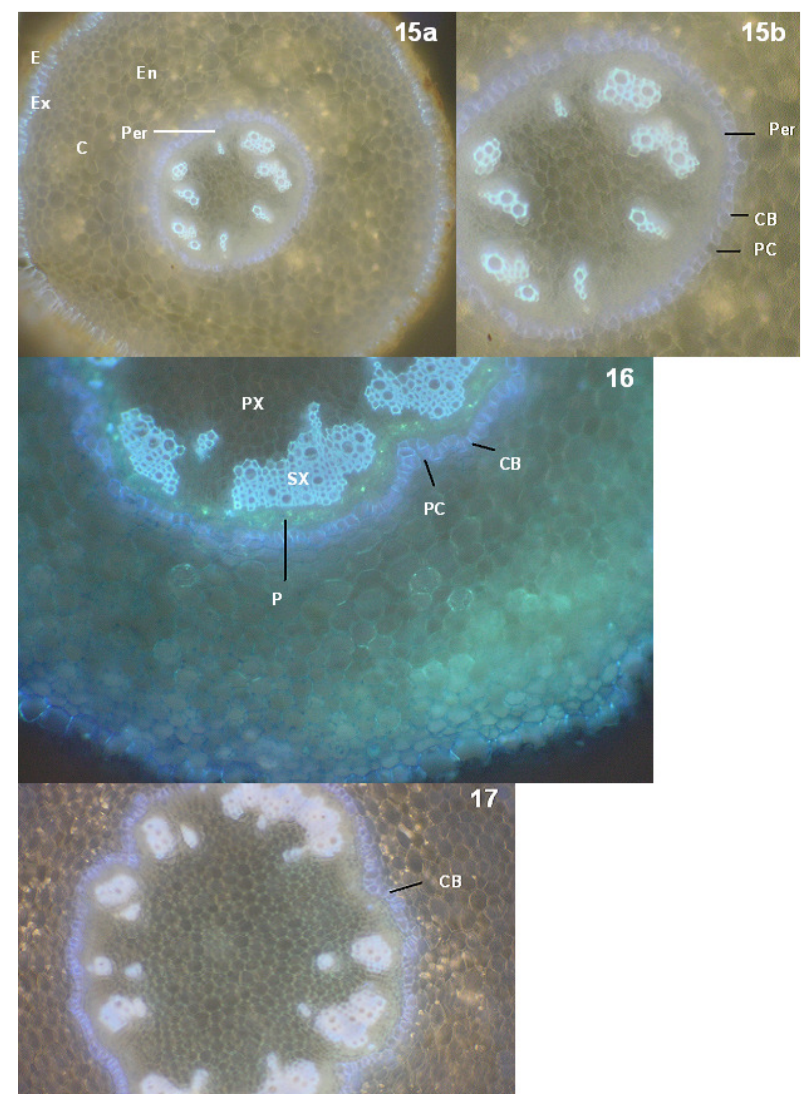

Figure 15a: Cross section of root unstained under the epifluorescence microscope showing epidermis (E), exodermis (Ex), cortex (C), endodermis (En) and pericycle (Per). b. Close up of endodermis showing Casparian bands (CB), a passage cell (PC), and the pericycle (Per).

Figure 16: Cross section of mature root stained with Analine Blue showing Casparian bands (CB), passage cells (PC), phloem (P), primary xylem (PX), and secondary xylem (SX). Growth of the endodermis is keeping pace with the expansion of the vascular cylinder.

Figure 17: Cross section of mature root unstained under the epifluorescence microscope again showing the Casparian bands (CB) in the endodermis.

\section{Epidermis}

In fresh epidermal peels and nail polish impressions, several features of the leaf epidermis were notable. First, there were many stomata on the abaxial (lower) side of the leaf whereas there were none found on the adaxial (upper) surface. The stomatal complexes consisted of a stomatal pore, two guard cells with chloroplasts, and subsidiary cells that surrounded the guard cells (Figure 22). The leaf surface was covered with a cuticle, and over some stomata there was a cuticular ledge (Figure 23). In between the stomata were irregular shaped pavement cells. Subsidiary cells around trichomes were also visible.

Oval-shaped cystolith crystals (calcium carbonate crystals) were quite numerous just under the epidermal layer
(Figure 24). When viewed under a compound microscope with polarizers, these crystals fluoresced.

\section{Trichomes}

There were several types of trichomes found on the adaxial and abaxial surfaces of the leaf. First, there were multicellular trichomes found on the abaxial surface of the leaf (Figure 25a) which resembled those on the stem. On the abaxial surface of the leaf, there were unicellular trichomes as well as glandular (secretory) trichomes (Figure 25b). The secretory trichomes had a head and several stalk cells. Together, these trichomes covered a large portion of the leaf surface.

\section{Inner Leaf Arrangement}

The leaf had a lot of chlorophyll which made it difficult to view the inner tissue structure unless the leaf was cleared. When cleared and sectioned, a layer of palisade mesophyll was evident under the epidermis of the adaxial surface of the leaf. There was a layer of spongy mesophyll just inside of the epidermis of the abaxial surface of the leaf (Figure 26). The vascular arrangement of the midvein was collateral, with xylem towards the adaxial surface and phloem forming a half ring around the xylem towards the abaxial surface (Figure 27). There were no signs of secondary vascular tissue in the leaf which is inconsistent with the secondary growth found in the stem and root.

\section{Flowers}

As described previously, white flowers were surrounded by three lime green-yellow bracts. There were four petals that were fused together to form a narrow tube roughly $1-2 \mathrm{~cm}$ in length. The petals were covered in tiny trichomes. There were also four small sepals just below the petals. Upon dissecting the flower under a dissecting microscope, it was determined that the flower is perfect and complete, meaning that it has both male and female reproductive parts and all four whorls (sepals, petals, carpel, and stamens). The flower also had a nectar chamber at the base of the petal tube.

\section{DISCUSSION}

At first glance, J. brandegeana appears to be a typical dicotyledonous flowering plant with its reticulate venation in the leaves, vascular tissue arranged in a ring in the stem, flowering parts in multiples of four, and so on. However, upon further inspection of the plant at the cellular level, it was determined that $J$. brandegeana actually has several unique anatomical features. Many of these features can be attributed to the semi-arid environment that this plant inhabits. There are many challenges for plants in this type of environment, including intense sun exposure, potential for high winds (not as much plant cover for protection), dry soils, and herbivorous ground animals. ${ }^{11}$ Many of the adaptations found in the shrimp plant help it to be resilient to these environmental challenges. 


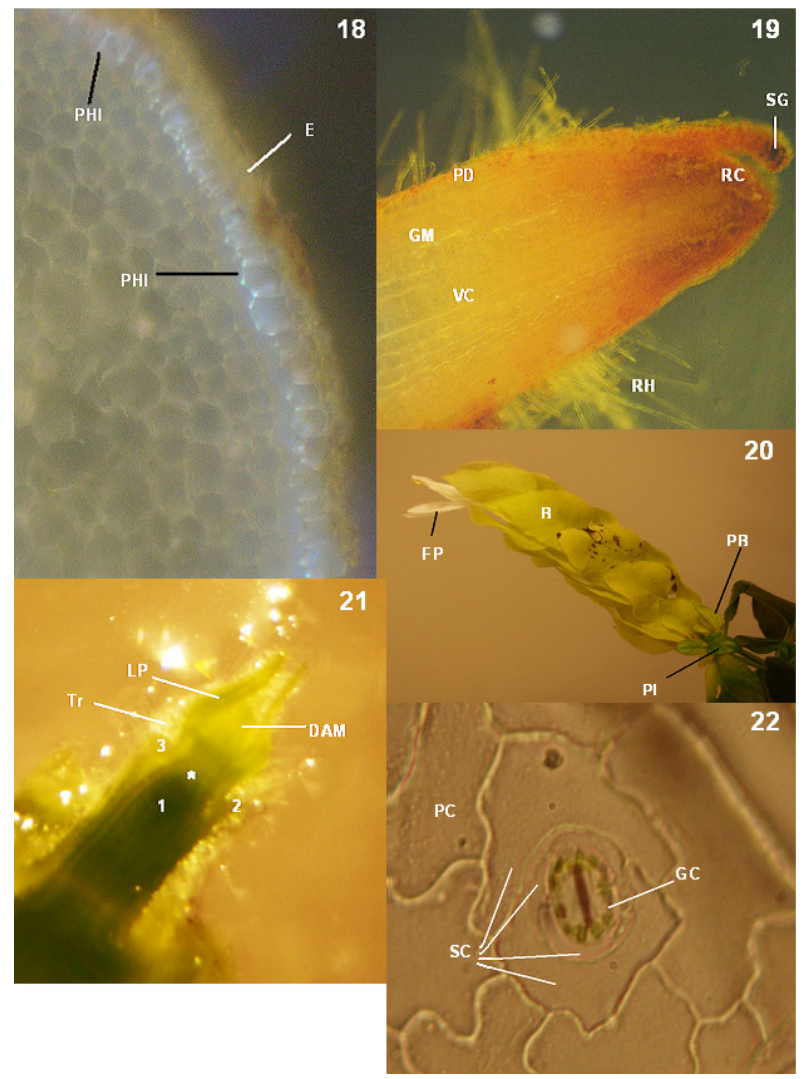

Figure 18: Cross section of mature root unstained under the epifluorescence microscope showing phi thickenings in cortical cells (PHI), and epidermal cells (E) that are degrading and sloughing off.

Figure 19: Longitudinal section of the root tip stained with $I_{2}$ KI showing the three primary meristems: protoderm (PD), ground meristem (GM), and vascular cambium (VC). Starch grains (SG) at the tip of the root cap (RC) are also visible although partially separated when sectioned.

Figure 20: Floral part showing bracts (B), flower petals (FP), primary bract (PB), and primary leaf (PL).

Figure 21: Longitudinal section of the shoot apical meristem under the dissecting microscope showing the domed apical meristem (DAM), leaf primordia (LP), trichomes (Tr), a developing axillary bud (*), and scars from removed leaf primordia $(1,2,3)$.

Figure 22: Fresh leaf peel of the abaxial surface showing pavement cells (PC), two guard cells (GC) around the stomatal opening and four subsidiary cells (SC).

To begin, the thick cuticle on the stem and leaf help protect the plant from excess water loss through evapotranspiration. The many trichomes on the stem and leaf also help to protect against direct sun exposure and insulate the plant from wind (which further reduces evapotranspiration). ${ }^{11}$ While the shrimp plant needs some sun energy to photosynthesize, it is a tradeoff between losing too much water from its tissues. Furthermore, the arrangement of stomata on the abaxial surface of the leaf as opposed to the adaxial surface is also a technique to preserve water by

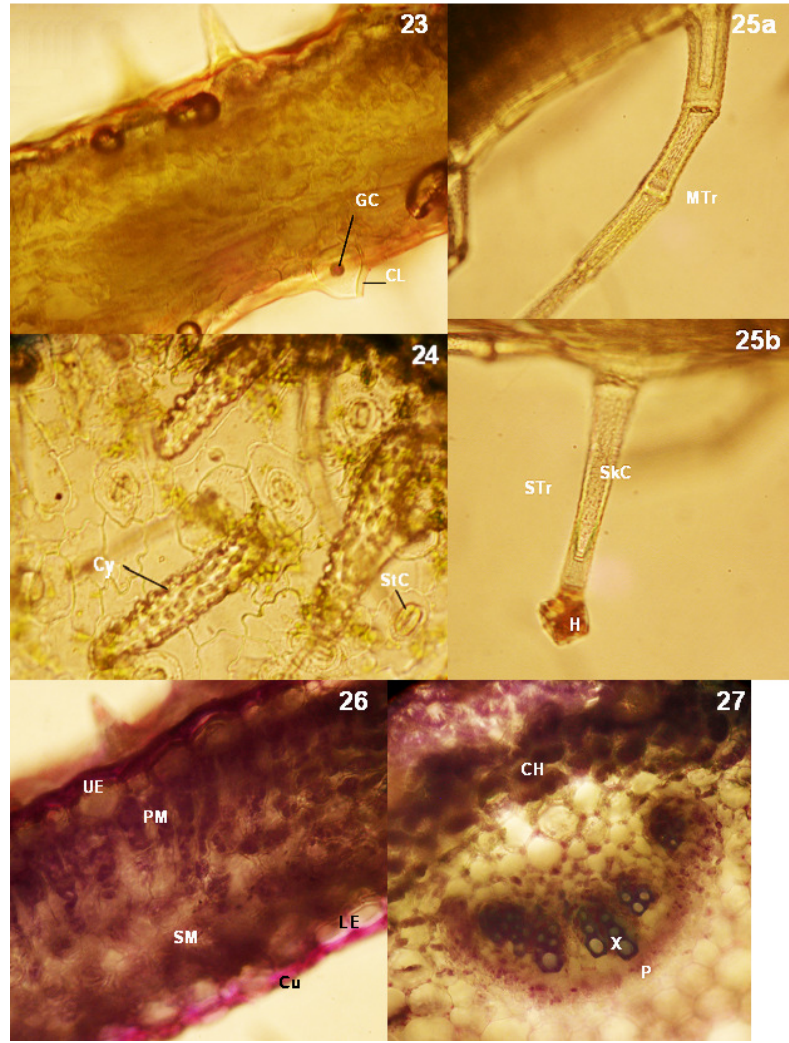

Figure 23: Cross section of cleared leaf stained with Sudan III/IV showing cuticular ledge (CL) around guard cells (GC) of stomata on abaxial surface of leaf.

Figure 24: Fresh leaf peel showing cystolith crystals (Cy) and stomata (StC).

Figure 25a: Multicellular trichome on abaxial surface of leaf (MTr). b. Secretory trichome (STr) on adaxial surface of leaf with stalk cells (SkC) and head (H).

Figure 26: Cross section of cleared leaf stained with TBO showing upper epidermis (UE), palisade mesophyll (PM), spongy mesophyll (SM), lower epidermis (LE), and cuticle (Cu).

Figure 27: Cross section of cleared lead stained with TBO showing vascular bundle in midvein with xylem (X) towards the adaxial surface and phloem (P) towards the abaxial side. Chlorenchyma $(\mathrm{CH})$ is also visible.

shading the stomata from the direct sun. ${ }^{11}$ The presence of stomata on the stem is likely because the lower surfaces of the rather small and sparse leaves are not sufficient to support the necessary gas exchange throughout the entire plant. The stomata on the stem are also limited to the areas where they are most needed (where photosynthesis is occurring close to the epidermis). All of these strategies help to protect the plant against excess water loss.

The vascular tissue in the stem and root of the shrimp plant are also characteristic of a plant that has adapted to a hot/dry environment. In almost all sections of the root and stem, there was a large amount of secondary xylem. Perhaps the large amount of secondary xylem is an adaptation in order to maximize the transfer of water from the roots to the rest of the plant when water is present. The layer of suberized 
parenchyma around the vascular tissue likely protects against water loss as well. The long, thin, fibrous roots maximize their surface area to volume ratio which also aids in rapid water absorption. Rainfall is sparse in a semi-arid environment and often evaporates or infiltrates down through the sand quite rapidly. ${ }^{11}$ The shrimp plant has adapted these features to quickly uptake this water before it is lost.

The shrimp plant has also adapted features to help protect it from the wind. The thick layer of collenchyma tissue allows the stem to be strong yet flexible. This feature is ideal for a shrub that needs support against the wind and protection from pests. Additionally, the thick band of secondary xylem forms a rather strong ring structure that not only transports water, but also helps to keep the stem from breaking under stress. The four ridges along the stem create a strong structure as well. Having a tough stem and leaf not only protects against wind, but also helps defend the plant from herbivores.

Since $J$. brandegeana is a shrub that is close to the ground, it is more susceptible to damage from ground herbivores. In terms of defensive strategies, the cystolith crystals in the stem deter pests since they are not palatable. ${ }^{8}$ Trichomes also prevent small animals and insects from reaching the plant surface. It was unclear what substance was secreted from the secretory trichomes, however it is likely an animal deterrent as well. Furthermore, the suberized parenchyma layer likely protects the vascular tissue from pests.

Altogether, the shrimp plant has adapted many features at the cellular level that help it to survive in its natural environment. Further research on the detailed anatomy of other plants that live in similar environments to the shrimp plant is necessary in order to see if these adaptations are common among similar plants.

\section{REFERENCES}

1) Scheper, J. (2007). Floridata: Justicia Brandegeana. Retrieved Nov. 3, 2009, from Floridata, Tallahassee, Florida. Web site: http://www.floridata.com/ref/j/just_bra.cfm.
2) McDade, L., Daniel, T., \& Kiel, C. (2008). Toward a comprehensive understanding of phylogenetic relationships among lineages of Acanthaceae S. L. (Lamiales). American Journal of Botany, 95(9), 1136-1152.

3) Natural Resources Conservation Service. (2009). PLANTS Profile for Justicia Brandegeeana (shrimpplant). Retrieved Nov. 5, 2009, from United States Department of Agriculture, United States. Web site: http://plants.usda.gov/java/profile?symbol=JUBR6.

4) Encyclopedia Britannica. (2009). Shrimp plant. Retrieved Nov. 6, 2009, from Encyclopedia Britannica Online, Chicago, Illinois. Web site: http://www.britannica.com/EBchecked/topic/542058/shrimpplant.

5) Wunderlin, R. P., and B. F. Hansen. (2008). Atlas of Florida vascular plants. Retrieved Nov. 8, 2009, from Florida Center for Community Design and Research, Institute for Systemic Botany, University of South Florida, Tampa. Web site: http://florida.plantatlas.usf.edu/SpecimenDetails.aspx?PlantI $\mathrm{D}=1599$.

6) McDade, L. \& Kiel, C. (2006). Acanthaceae. Retrieved Nov. 5, 2009, from Tree of Life Web Project, University of Arizona. Web site: http://tolweb.org/acanthaceae/20878. 7) Gilman, E. F. \& Meerow, A. (2000). Pacystachys Lutea. Retrieved Nov. 8, 2009, from Cooperative Extension Service -- Institute of Food and Agricultural Sciences, University of Florida. Web site: http://hort.ifas.ufl.edu/shrubs/PACLUTA.PDF.

8) Esau, K. (1953). Plant anatomy. New York, NY: John Wiley and Sons, Inc.

9) Peterson, R. L., Peterson, C. A., \& Melville, L. H. (2008). Teaching plant anatomy through creative laboratory exercises. Ottawa, ON: National Research Council of Canada.

10) Peterson, L., J. Greenwood, B. Lee, D. McClellan. (2009). Plant anatomy $\left(B O\right.$ * $\left.^{*} 3410\right)$ laboratory exercises. University of Guelph, Department of Molecular and Cellular Biology.

11) Graham, L., Graham, J., \& Wilcox, W. (2006). Arid terrestrial ecosystems. In C. Trueheart (Ed.), Plant biology (pp. 482-511). Saddle River, NJ: Pearson Prentice Hall. 